\title{
Perbandingan Algoritma LVQ dan RBFNN Untuk Identifikasi Glaukoma dan Diabetes Retinopati Pada Citra Fundus
}

\author{
${ }^{1}$ Kevin Oktavius, ${ }^{2}$ Siska Devella,M. Kom. \\ STMIK GI MDP; Jalan Rajawali 14, Palembang, 0711-376-400 \\ Jurusan Ilmu Komputer, STMIK GI MDP, Palembang \\ e-mail: ${ }^{1}$ kevinokt@mhs.mdp.ac.id, ${ }^{2}$ siskadevella@mdp.ac.id
}

\begin{abstract}
Abstrak
Penyakit mata merupakan salah satu masalah kesehatan utama pada semua orang terutama pada kaum lansia, penyakit mata yang paling umum menyerang lansia diantaranya adalah glaukoma dan retinopati diabetes. Penyakit glaukoma dan diabetes retinopati dapat diketahui melalui citra fundus. Pada penelitian ini telah dilakukan perbandingan algoritma Learning Vector Quantization dengan Radial Basis Function Neural Network untuk klasifikasi penyakit glaukoma dan diabetes retinopati (accuracy, precision, recall) berdasarkan citra fundus resolusi tinggi. Dataset yang digunakan berjumlah 45 citra fundus yang terdiri dari 15 citra fundus terjangkit glaukoma, 15 citra fundus terjangkit diabetes retinopati dan 15 citra fundus mata normal. Pada perhitungan dengan confusion matrix hasil tertinggi didapatkan pada algoritma radial basis function neural network dengan spread $=20$ dan $M N=10$ menghasilkan rata-rata accuracy sebesar $81,06 \%$, precision sebesar 80,83\% dan recall sebesar 73,33\% jika dibandingkan dengan algoritma learning vector quantization dengan lvqnet $=50$ dan epoch $=45$ menghasilkan rata-rata accuracy sebesar $80,85 \%$, precision sebesar 73,33\% dan recall sebesar $77,14 \%$.
\end{abstract}

Kata kunci: : Identifikasi, Glaukoma, Diabetes Retinopati, Fundus, Learning Vector Quantization, Radial Basis Function Neural Network.

\begin{abstract}
Eye disease is one of the major health problems in all people, especially in the elderly, the most common eye diseases affecting the elderly include glaucoma and diabetic retinopathy. Glaucoma and diabetic retinopathy can be identified through fundus images. In this research, a comparison of Learning Vector Quantization algorithm with Radial Basis Function Neural Network algorithm has been carried out for the classification of glaucoma and diabetes retinopathy (accuracy, precision, recall) based on high resolution fundus images. The dataset used was 45 fundus images consisting of 15 fundus images infected with glaucoma, 15 fundus images affected by diabetic retinopathy and 15 normal eye fundus images. In the calculation with the confusion matrix the highest results obtained in the Radial Basis Function Neural Network algorithm with spread = 20 and $M N=10$ produce an average accuracy of $81.06 \%$, precision of $80.83 \%$ and recall of $73.33 \%$ when compared with Learning vector quantization algorithm with lvqnet $=50$ and epoch $=45$ produces an average accuracy of $80.85 \%$, precision of $73.33 \%$ and recall of $77.14 \%$.
\end{abstract}

Keywords: Identification, Glaucoma, Retinopathy Diabetic, Fundus, Learning Vector Quantization, Radial Basis Function Neural Network. 


\section{PENDAHULUAN}

$\mathrm{P}$ enyakit mata merupakan salah satu masalah kesehatan utama pada semua orang terutama pada kaum lansia, penyakit mata yang paling umum menyerang lansia diantaranya adalah glaukoma dan diabetes retinopati. Penyakit Glaukoma dan diabetes retinopati dapat diketahui dari citra fundus. Glaukoma merupakan penyakit mata yang ditandai oleh tekanan bola mata yang meningkat, ekskavasi dan atrofi papil saraf optik, serta mengalami kerusakan lapang pandang. Gejala glaukoma umumnya meliputi rasa sakit yang luar biasa pada mata, sakit kepala, penglihatan kabur, dan menciutnya lapang pandang (Tobias \& Widiarti, 2016). Diabetes retinopati merupakan suatu mikroangiopati progresif yang ditandai oleh kerusakan dan sumbatan terjadi pada pembuluh darah halus retina. Kelainan patologik yang paling dini adalah penebalan membran basal endotel kapiler dan penurunan jumlah perisit. Klasifikasi diabetes retinopati dibagi menjadi 2, yaitu Non-Proliferatif Diabetic Retinopathy (NPDR), dan Preproliferatif Diabetic Retinopathy (PDR). NPDR adalah stage awal dari diabetes retinopati, pada stage ini, pembuluh darah kecil pada retina akan mengalami pendarahan atau bocor, cairan yang bocor ini menyebabkan retina mata mengalami bengkak dan membentuk gumpalan-gumpalan (Aulia dkk., 2015).

Ada beberapa penelitian yang telah melakukan klasifikasi mengenai penyakit glaukoma dan diabetes retinopati yaitu Al Rivan \& Juangkara (2019) melakukan penelitian tentang identifikasi potensi glaukoma dan diabetes retinopati melalui citra fundus menggunakan jaringan syaraf tiruan yaitu metode backpropagation. Hasil dari penelitian menghasilkan rata-rata recall sebesar 86,6\%, rata-rata precission sebesar 86,6\% dan untuk rata-rata accuracy sebesar 91,66\%. Satyarthi dkk. (2016) melakukan penelitian yang berjudul detection of diabetic retinopathy in fundus images using vector quantization technique. Penelitian ini menggunakan Gaussian Intensity untuk klasifikasi diabetes retinopati lalu input fitur ke penggolongan vector quantization. Penelitian ini menghasilkan nilai akurasi sebesar 90\% dalam mengidentifikasi penyakit diabetes retinopati pada citra fundus. Arifianto \& Sarosa (2014) melakukan penelitian klasifikasi stroke berdasarkan kelainan patologis dengan Learning Vector Quantization. Hasil penelitian menunjukkan bahwa penggunaan metode Learning Vector Quantization dapat menghasilkan akurasi $90 \%$.

Penelitian terdahulu mengenai klasifikasi menggunakan Radial Basis Function Neural Network yaitu Santosa dkk. (2017) melakukan penelitian tentang model prediksi penyakit ginjal kronik menggunakan radial basis function neural network. Hasil penelitian menunjukkan bahwa penggunaan radial basis function neural network untuk penyakit ginjal kronik menghasilkan akurasi sebesar 93,75\%. Hariyanto dkk. (2016) melakukan penelitian klasifikasi penyakit mata katarak berdasarkan kelainan patologis dengan menggunakan algoritma Learning Vector Quantization. Hasil penelitian menunjukkan bahwa penggunaan Learning Vector Quantization dapat menghasilkan akurasi sebesar 99\%. Arifianto \& Sarosa (2014) melakukan penelitian klasifikasi stroke berdasarkan kelainan patologis dengan Learning Vector Quantization. Hasil penelitian tersebut menunjukkan bahwa penggunaan metode Learning Vector Quantization mendapatkan hasil akurasi sebesar $90 \%$.

Metode klasifikasi radial basis function neural network dan learning vector quantization memberikan hasil tingkat akurasi yang baik dalam mengklasifikasi suatu objek. Maka, dilakukan penelitian mengenai perbandingan algoritma LVQ dan RBFNN untuk identifikasi glaukoma dan diabetes retinopati pada citra fundus.

Oktavianus, et., al (Perbandingan Algoritma LVQ dan RBFNN Untuk Identifikasi Glaukoma dan Diabetes Retinopati Pada Citra Fundus) 


\section{METODE PENELITIAN}

Berikut ini adalah tahapan rancangan metode yang diterapkan untuk membandingkan metode radial basis function neural network dan learning vector quantization untuk identifikasi glaucoma dan diabetes retinopati pada citra fundus.

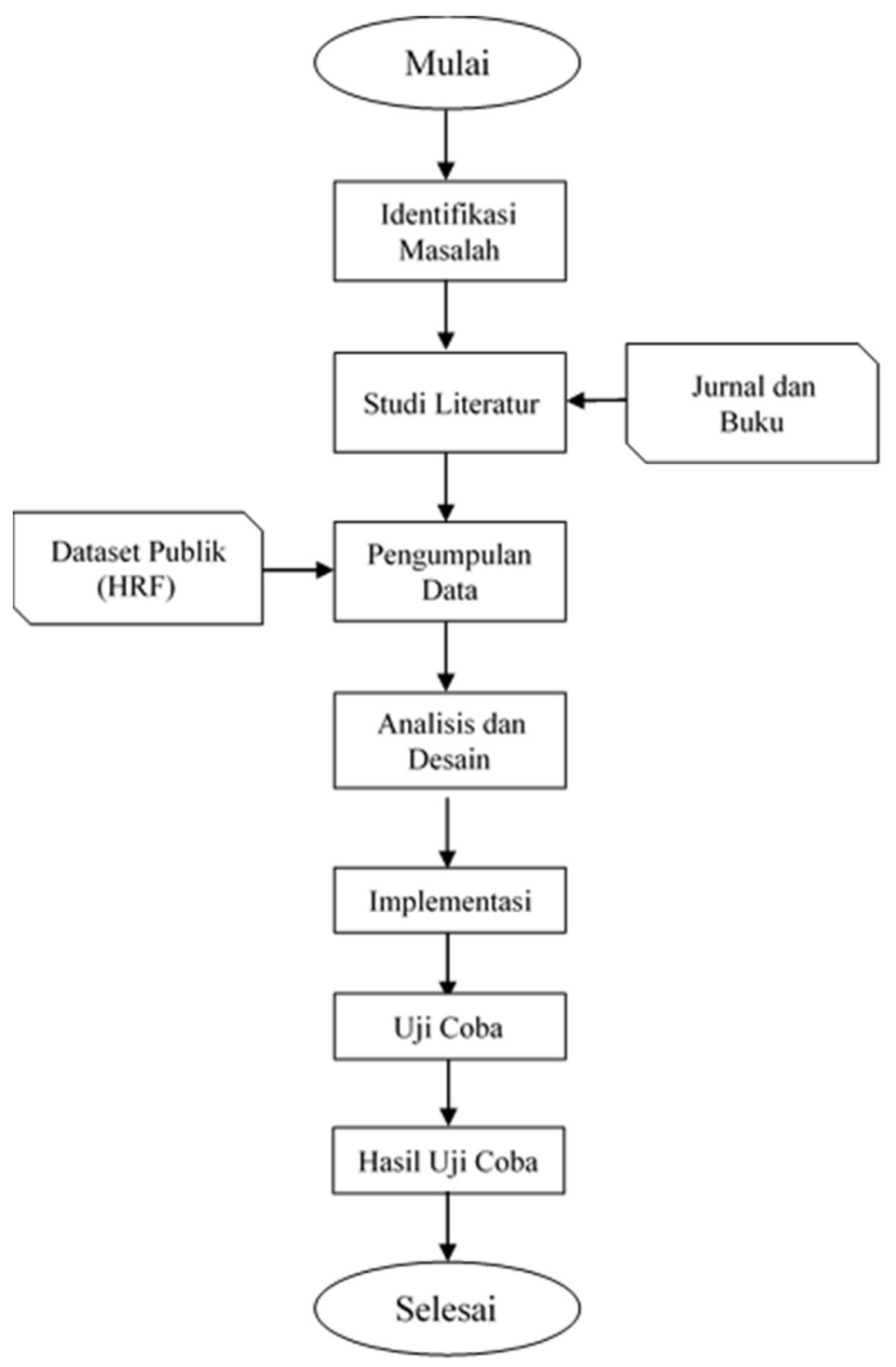

Gambar 1 Metodologi Penelitian

\subsection{Identifikasi Masalah}

Penelitian ini dilakukan dari mencari topik mengenai pendeteksian penyakit mata pada citra fundus. Pada tahapan ini, melakukan analisis mengenai metode yang tleah diuji untuk mendeteksi penyakit mata pada citra fundus.

\subsection{Studi Literatur}

Pada tahapan ini, dilakukan pencarian beberapa jurnal, buku dan hasil penelitian yang berkaitan dengan pendeteksian penyakit mata pada citra fundus menggunakan berbagai macam

Oktavianus, et., al Perbandingan Algoritma LVQ dan RBFNN Untuk Identifikasi Glaukoma dan Diabetes Retinopati Pada Citra Fundus 
Vol. 1, No. 1, Oktober 2020, Hal. 68 - 78

metode, jurnal yang terkait dengan Radial Basis Function Neural Network dan Learning Vector Quantization karena RBFNN dan LVQ dapat bekerja secara efektif pada citra.

\subsection{Analisis dan Desain}

Analisis dan desain (Gambar 2 dan Gambar 3) dilakukan dengan mengumpulkan dataset citra fundus yang terinfeksi glaukoma, diabetes retinopati dan tidak. Kemudian dilanjutkan dengan melakukan perancangan sistem Radial Basis Function dan Learning Vector Quantization. Proses Training dilakukan menginput citra fundus yang telah didapatkan dari dataset untuk dilakukan training citra fundus tersebut. Pada proses testing dilakukan menginput citra dari dataset ke dalam model data training lalu dihasilkan jenis fundus yang telah diklasifikasi.

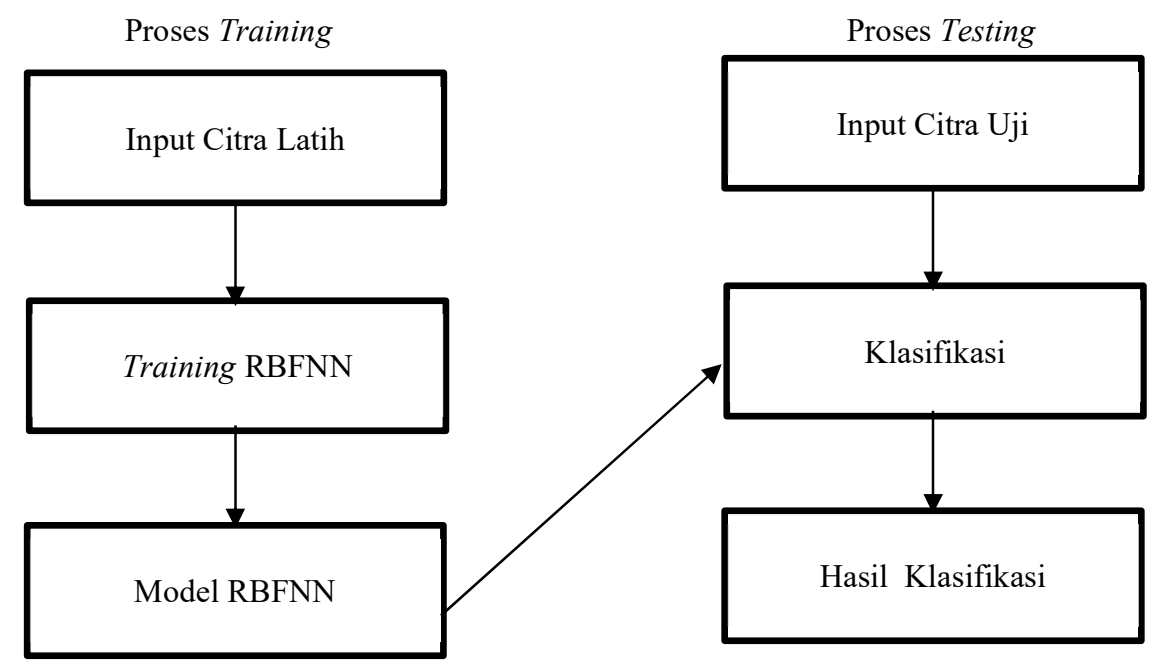

Gambar 2 Tahapan Analisis dan Desain RBFNN

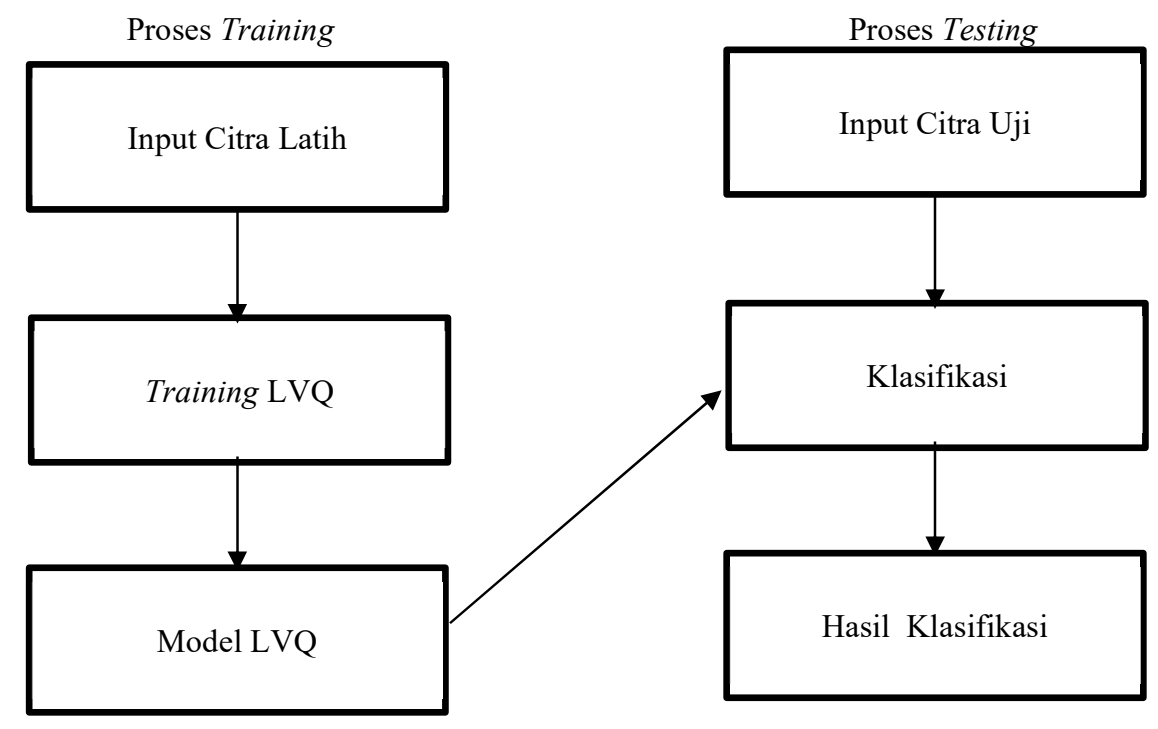

Gambar 3 Tahapan Analisis dan Desain LVQ

Oktavianus, et., al (Perbandingan Algoritma LVQ dan RBFNN Untuk Identifikasi Glaukoma dan Diabetes Retinopati Pada Citra Fundus) 


\subsection{Implementasi}

Setelah melakukan analisis dan desain, tahap selanjutnya adalah melakukan implementasi terhadap sistem Radial Basis Function Neural Network dan Learning Vector Quantization dengan menggunakan MATLAB.

\subsection{Uji Coba}

Pengujian program dilakukan untuk memastikan semua bagian berjalan sesuai dengan tujuan. Tujuan tahap ini adalah untuk meminimalisir kesalahan dan memastikan keluaran yang dihasilkan sesuai dengan keinginan. Hasil pengujian akan didokumentasikan dalam bentuk tabel dengan parameter precision, recall, accuracy. Precision, recall, accuracy dihitung dengan rumus.

$$
\begin{aligned}
& \text { Precision }=\frac{T P}{F N} \\
& \text { Recall }=\frac{T P}{T P+F N} \\
& \text { Accuracy }=\frac{T P+T N}{T P+T N+F P+F}
\end{aligned}
$$

Keterangan :

$\mathrm{TP}=$ Jumlah data positif citra fundus yang terklasifikasi dengan benar oleh sistem.

$\mathrm{TN}=$ Jumlah data negatif citra fundus yang terklasifikasi dengan benar oleh sistem.

$\mathrm{FN}=$ Jumlah data negatif citra fundus namun terklasifikasi salah satu sistem.

$\mathrm{FP}=$ Jumlah data positif citra fundus namun terklasifikasi salah satu sistem.

\section{HASIL DAN PEMBAHASAN}

Pada tahapan ini merupakan tahapan dalam mengimplementasikan proses penelitian bertujuan untuk memperoleh hasil pada penelitian ini, implementasi meliputi tahapan klasifikasi RBFNN dan LVQ. Menggunakan citra latih yang berjumlah 30 citra fundus dan citra uji berjumlah 15 citra fundus yang mendapatkan hasil akurasi terbaik.

\subsection{Implementasi Klasifikasi Metode RBFNN}

Pada tahapan ini, implementasi klasifikasi RBFNN akan memproses citra tersebut sehingga didapatkan hasil berupa model. Model yang didapatkan akan digunakan untuk proses testing. Hasil pengujian yang diperoleh diuji dengan menggunakan Spread=10, Spread=20, Spread=30 serta menggunakan MN=10. MN adalah Maximum Number of Neurons.

\subsubsection{Hasil Pengujian Menggunakan Klasifikasi RBFNN dengan Spread=10 dan $M N=10$}

Berdasarkan hasil pengujian dengan menggunakan spread 10 dan Mn 10 didapatkan rata rata accuracy sebesar $80.85 \%$, precission sebesar $85.19 \%$, dan recall sebesar $73.33 \%$. Hasil

\begin{tabular}{|c|c|c|c|c|c|c|c|}
\hline Kelas & $\mathbf{T P}$ & $\mathbf{T N}$ & FP & $\mathbf{F N}$ & Accuracy(\%) & Precision(\%) & Recall(\%) \\
\hline Diabetes Retinopati & 3 & 8 & 0 & 2 & 84.62 & 100.00 & 60.00 \\
\hline Glaukoma & 3 & 8 & 0 & 2 & 84.62 & 100.00 & 60.00 \\
\hline Normal & 5 & 6 & 4 & 0 & 73.33 & 55.56 & 100.00 \\
\hline \multicolumn{5}{|c|}{ Rata-rata } & 80.85 & 85.19 & 73.33 \\
\hline
\end{tabular}
accuracy, precission, dan recall dapat dilihat pada Tabel 1.

Tabel 1 Hasil Accuracy, Precission, dan recall dengan menggunakan Spread=10 dan $M N=10$

Oktavianus, et., al Perbandingan Algoritma LVQ dan RBFNN Untuk Identifikasi Glaukoma dan Diabetes Retinopati Pada Citra Fundus 
Vol. 1, No. 1, Oktober 2020, Hal. 68 - 78

\subsubsection{Hasil Pengujian Menggunakan Klasifikasi RBFNN dengan Spread=20 dan $M N=10$}

Berdasarkan hasil pengujian dengan menggunakan spread 20 dan Mn 10 didapatkan hasil terbaik dengan hasil accuracy sebesar $81.06 \%$, precission sebesar $80.83 \%$, dan recall sebesar $73.33 \%$. Hasil accuracy, precission, dan recall dapat dilihat pada Tabel 2.

Tabel 2 Hasil Accuracy, Precission, dan recall dengan menggunakan Spread=20 dan $M N=10$

\begin{tabular}{|c|c|c|c|c|c|c|c|}
\hline Kelas & TP & TN & FP & FN & Accuracy(\%) & Precision(\%) & Recall(\%) \\
\hline Diabetes Retinopati & 2 & 9 & 0 & 3 & 78.57 & 100.00 & 40.00 \\
\hline Glaukoma & 4 & 7 & 1 & 1 & 84.62 & 80.00 & 80.00 \\
\hline Normal & 5 & 7 & 3 & 0 & 80.00 & 62.50 & 100.00 \\
\hline \multicolumn{5}{|c|}{ Rata-rata } & 81.06 & 80.83 & 73.33 \\
\hline
\end{tabular}

3.2.3 Hasil Pengujian Menggunakan Klasifikasi RBFNN dengan Spread=30 dan MN=10

Berdasarkan hasil pengujian dengan menggunakan spread 30 dan Mn 10 didapatkan hasil terbaik dengan hasil accuracy sebesar $75 . \%$, precission sebesar $80,83 \%$, dan recall sebesar $73,33 \%$. Hasil accuracy, precission, dan recall dapat dilihat pada Tabel 3.

Tabel 3 Hasil Accuracy, Precission, dan recall dengan menggunakan Spread=30 dan $M N=10$

\begin{tabular}{|c|c|c|c|c|c|c|c|}
\hline Kelas & TP & $\mathbf{T N}$ & FP & FN & Accuracy(\%) & Precision(\%) & Recall(\%) \\
\hline Diabetes Retinopati & 2 & 8 & 0 & 3 & 76.92 & 76.92 & 76.92 \\
\hline Glaukoma & 4 & 6 & 2 & 1 & 76.92 & 76.92 & 76.92 \\
\hline Normal & 4 & 6 & 3 & 1 & 71.43 & 71.43 & 71.43 \\
\hline \multicolumn{5}{|c|}{ Rata-rata } & 75.09 & 75.09 & 75.09 \\
\hline
\end{tabular}

\subsection{Implementasi Klasifikasi Metode LVQ}

Pada tahapan ini, implementasi klasifikasi LVQ akan memproses citra tersebut sehingga didapatkan hasil berupa model. Model yang didapatkan akan digunakan untuk proses testing. Hasil pengujian yang diperoleh diuji dengan menggunakan lvqnet=50 serta menggunakan epoch $=40$, epoch $=45$, epoch $=50$.

\subsubsection{Hasil Pengujian dengan Menggunakan Klasifikasi LVQ dengan lvqnet 50 dan epoch 40}

Berdasarkan hasil pengujian dengan menggunakan lvqnet 50 dan epoch 40 didapatkan hasil accuracy sebesar $75.40 \%$, precission sebesar $66.67 \%$, dan recall sebesar $76.19 \%$. Hasil accuracy, precission, dan recall dapat dilihat pada Tabel 4.

Tabel 4 Hasil Accuracy, Precission, dan recall dengan menggunakan lvqnet 50 dan epoch 40

\begin{tabular}{|c|c|c|c|c|c|c|c|}
\hline Kelas & TP & TN & FP & FN & Accuracy(\%) & Precision(\%) & Recall(\%) \\
\hline Diabetes Retinopati & 5 & 5 & 0 & 2 & 83.33 & 100.00 & 71.43 \\
\hline Glaukoma & 4 & 6 & 1 & 3 & 71.43 & 80.00 & 57.14 \\
\hline Normal & 1 & 9 & 4 & 0 & 71.43 & 20.00 & 100.00 \\
\hline \multicolumn{5}{|c|}{ Rata-rata } & 75.40 & 66.67 & 76.19 \\
\hline
\end{tabular}

3.2.2 Hasil Pengujian dengan Menggunakan Klasifikasi LVQ dengan lvqnet 50 dan epoch 45

Berdasarkan hasil pengujian dengan menggunakan lvqnet 50 dan epoch 45 didapatkan hasil accuracy sebesar $80,85 \%$, precission sebesar $73,33 \%$, dan recall sebesar $77,14 \%$. Hasil accuracy, precission, dan recall dapat dilihat pada Tabel 5.

Oktavianus, et., al (Perbandingan Algoritma LVQ dan RBFNN Untuk Identifikasi Glaukoma dan Diabetes Retinopati Pada Citra Fundus) 
Tabel 5 Hasil Accuracy, Precission, dan recall dengan menggunakan lvqnet 50 dan epoch 45

\begin{tabular}{|c|c|c|c|c|c|c|c|}
\hline Kelas & TP & TN & FP & FN & Accuracy(\%) & Precision(\%) & Recall(\%) \\
\hline Diabetes Retinopati & 5 & 6 & 0 & 2 & 84,62 & 100,00 & 71,43 \\
\hline Glaukoma & 3 & 8 & 2 & 2 & 73,33 & 60,00 & 60,00 \\
\hline Normal & 3 & 8 & 2 & 0 & 84,62 & 60,00 & 100,00 \\
\hline \multicolumn{7}{|c|}{ Rata-rata } & \\
\hline
\end{tabular}

3.2.3 Hasil Pengujian dengan Menggunakan Klasifikasi LVQ dengan lvqnet 50 dan epoch 50

Berdasarkan hasil pengujian dengan menggunakan lvqnet 50 dan epoch 50 didapatkan hasil accuracy sebesar $80,85 \%$, precission sebesar $73,33 \%$, dan recall sebesar $77,14 \%$. Hasil accuracy, precission, dan recall dapat dilihat pada Tabel 6.

Tabel 6 Hasil Accuracy, Precission, dan recall dengan menggunakan lvqnet 50 dan epoch 50

\begin{tabular}{|c|c|c|c|c|c|c|c|}
\hline Kelas & $\mathbf{T P}$ & $\mathbf{T N}$ & FP & FN & Accuracy(\%) & Precision(\%) & Recall(\%) \\
\hline Diabetes Retinopati & 5 & 6 & 0 & 2 & 84,62 & 100,00 & 71,43 \\
\hline Glaukoma & 3 & 8 & 2 & 2 & 73,33 & 60,00 & 60,00 \\
\hline Normal & 3 & 8 & 2 & 0 & 84,62 & 60,00 & 100,00 \\
\hline \multicolumn{5}{|c|}{ Rata-rata } & 80,85 & 73,33 & 77,14 \\
\hline
\end{tabular}

\subsection{Grafik Hasil Pengujian Menggunakan Klasifikasi RBFNN}

Berdasarkan grafik pada Gambar 3 dapat disimpulkan bahwa nilai accuracy perclass yaitu Diabetes Retinopati, Glaukoma dan Normal menggunakan klasifikasi RBFNN dengan nilai spread adalah 10, 20 dan 30 serta nilai $\mathrm{MN}=30$ maka diperolah rata - rata accuracy class Diabetes Retinopati adalah sebesar $80.86 \%$, Glaukoma sebesar $81.06 \%$ dan Normal sebesar 75.09\%. Class Glaukoma memperoleh akurasi klasifikasi terbesar dibandingkan dua kelas lainnya.

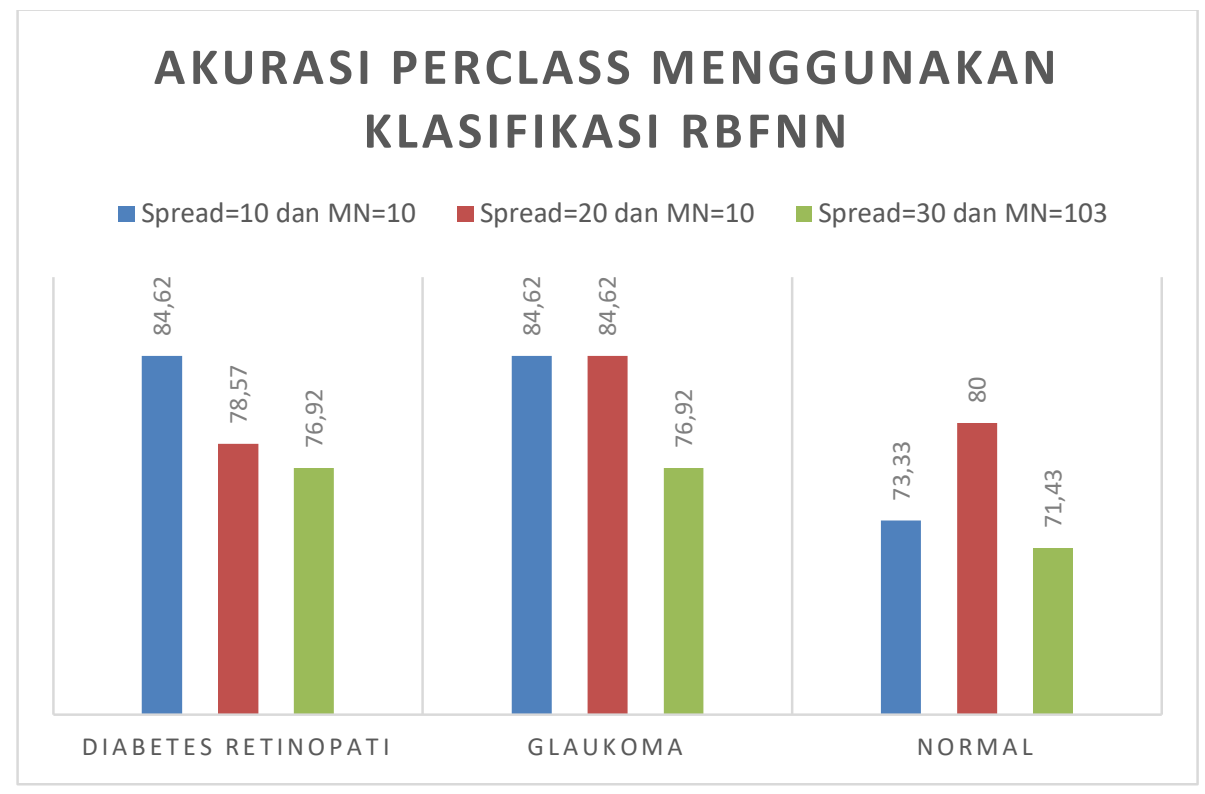

Gambar 3 Grafik Hasil Accuracy perclass dengan Menggunakan Klasifikasi RBFNN

Oktavianus, et., al Perbandingan Algoritma LVQ dan RBFNN Untuk Identifikasi Glaukoma dan Diabetes Retinopati Pada Citra Fundus 
Vol. 1, No. 1, Oktober 2020, Hal. 68 - 78

Berdasarkan grafik pada Gambar 4 dapat disimpulkan bahwa nilai accuracy terbesar adalah $81.06 \%$ untuk nilai Spread $=20$ dan $\mathrm{Mn}=10$ dan Nilai precission terbesar adalah $85.19 \%$ untuk nilai Spread $=10$ dan $\mathrm{Mn}=10$.

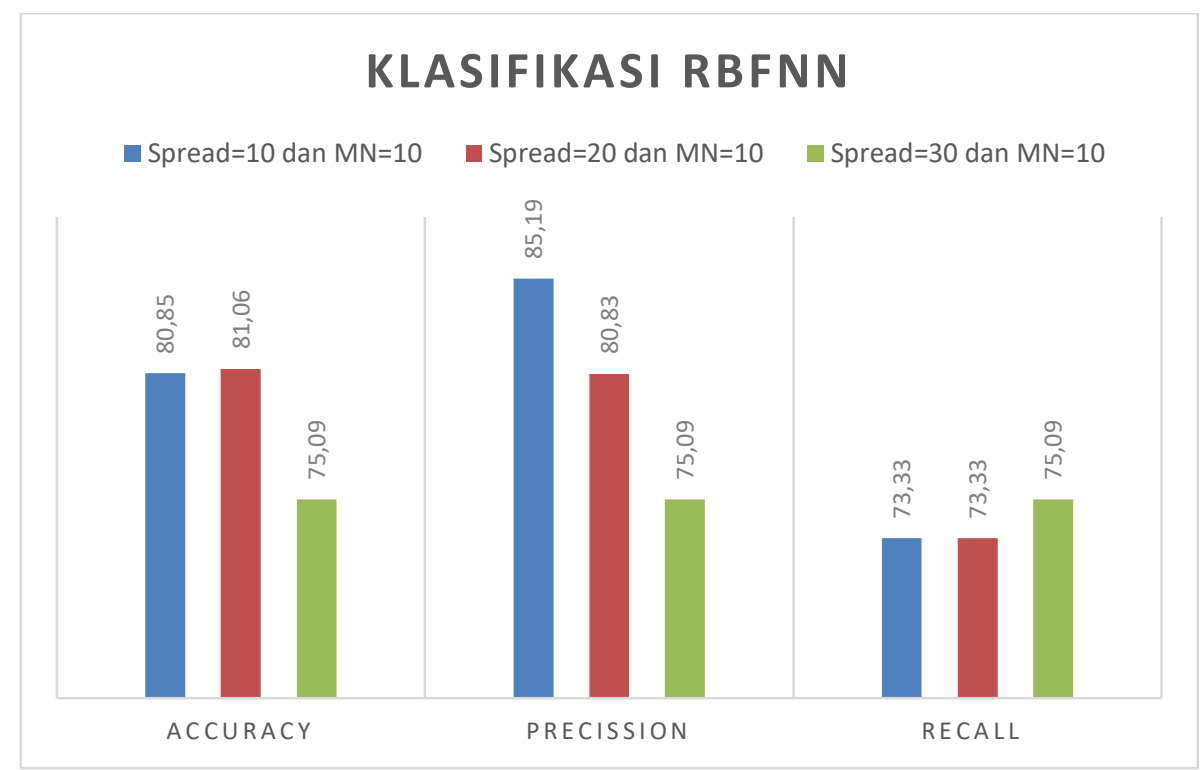

Gambar 4 Grafik Hasil Accuracy, Precision dan Recall dengan Menggunakan Klasifikasi RBFNN

\subsection{Grafik Hasil Pengujian Menggunakan Klasifikasi LVQ}

Berdasarkan grafik pada Gambar 5 dapat disimpulkan bahwa nilai accuracy perclass yaitu Diabetes Retinopati, Glaukoma dan Normal menggunakan klasifikasi LVQ dengan nilai epoch adalah 40, 45 dan 50 serta nilai lvqnet $=50$ maka diperolah rata - rata accuracy class Diabetes Retinopati adalah sebesar $84.19 \%$, Glaukoma sebesar $72.70 \%$ dan Normal sebesar $80.22 \%$. Class Diabetes Retinopati memperoleh akurasi klasifikasi terbesar dibandingkan dua kelas lainnya.

\section{AKURASI PERCLASS MENGGUNAKAN KLASIFIKASI LVQ}

- Ivqnet=50 dan epoch=40 Ivqnet=50 dan epoch=45 Ivqnet=50 dan epoch=50
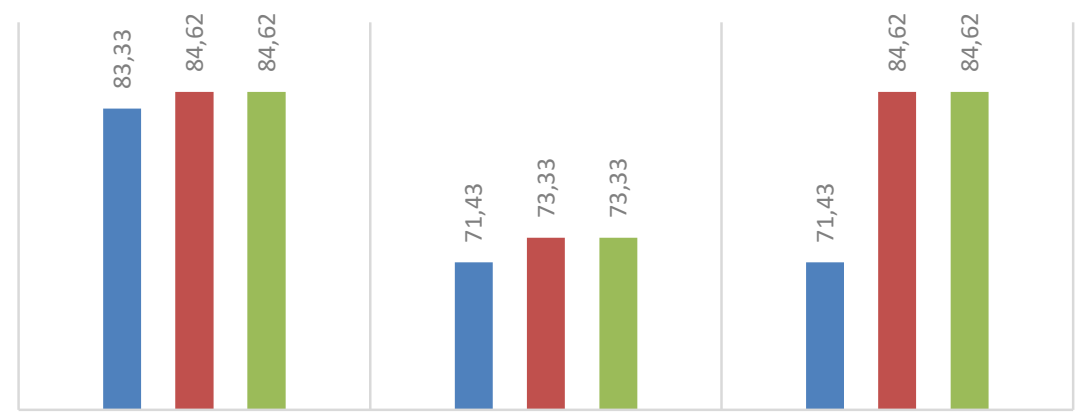

DIABETES RETINOPATI

GLAUKOMA

NORMAL

Gambar 5 Grafik Hasil Accuracy perclass dengan Menggunakan Klasifikasi LVQ

Oktavianus, et., al (Perbandingan Algoritma LVQ dan RBFNN Untuk Identifikasi Glaukoma dan Diabetes Retinopati Pada Citra Fundus) 
Berdasarkan grafik pada Gambar 6 dapat disimpulkan bahwa nilai accuracy terbesar adalah $80.85 \%$ untuk nilai lvqnet $=50$ dengan nilai epoch $=45$ dan 50 .

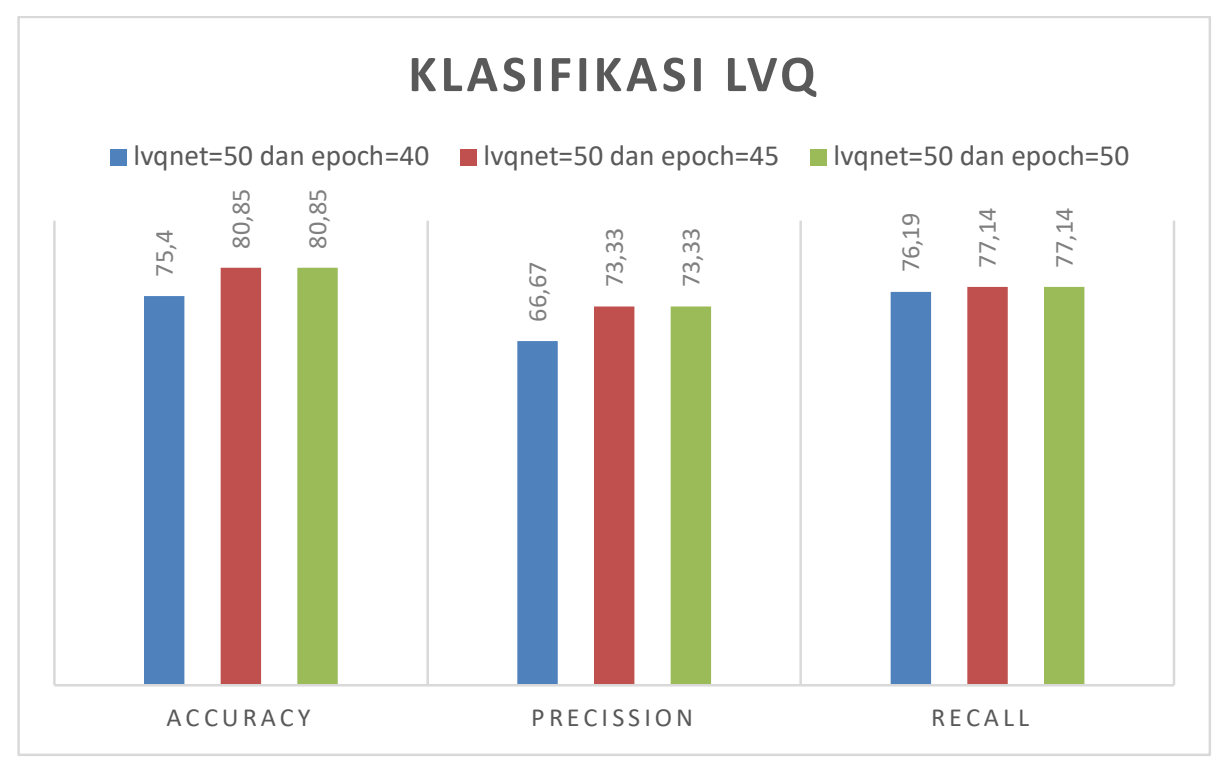

Gambar 6 Grafik Hasil Accuracy, Precision dan Recall dengan Menggunakan Klasifikasi LVQ

\section{KESIMPULAN}

Penelitian ini mempresentasikan suatu perbandingan antara algoritma RBFNN dan LVQ sebagai classifiers penyakit glaukoma dan diabetes retinopati berdasarkan citra fundus yang terdiri dari 30 citra latih dan 15 citra uji dari citra fundus. Berdasarkan penelitian yang telah dilakukan, terdapat beberapa kesimpulan yang dapat diperoleh, yaitu sebagai berikut:

1. Class Glaukoma memperoleh rata - rata akurasi klasifikasi terbesar dibandingkan dua kelas lainnya dengan menggunakan klasifikasi RBFNN.

2. Class Diabetes Retinopati memperoleh rata - rata akurasi klasifikasi terbesar dibandingkan dua kelas lainnya dengan menggunakan klasifikasi LVQ.

3. Klasifikasi menggunakan algoritma RBFNN diperoleh tingkat akurasi maksimum sebesar $81,06 \%$ dengan Spread $=20$ dan $\mathrm{MN}=10$.

4. Klasifikasi menggunakan algoritma LVQ diperoleh tingkat akurasi maksimum sebesar $80,85 \%$ dengan lvqnet $=50$ dan epoch $=45$.

5. Hasil akurasi klasifikasi menggunakan RBFNN lebih baik jika dibandingkan dengan klasifikasi LVQ.

\section{SARAN}

Berdasarkan penelitian yang telah dilakukan, terdapat saran untuk penelitian selanjutnya, yaitu melakukan perbandingan akurasi dengan menambahkan ektraksi fitur pada Citra Fundus High Resolution seperti ekstraksi HOG.

Oktavianus, et., al Perbandingan Algoritma LVQ dan RBFNN Untuk Identifikasi Glaukoma dan Diabetes Retinopati Pada Citra Fundus 


\section{DAFTAR PUSTAKA}

[1] Tobias, D. S., \& Widiarti, A. R. (2016). Deteksi glaukoma pada citra fundus retina dengan metode K-Nearest Neighbor. Snik, 92-99.

[2] Aulia, S., Hadiyoso, S., \& Ramadan, D. N. (2015). Analisis perbandingan knn dengan SVM untuk klasifikasi penyakit diabetes retinopati berdasarkan citra eksudat dan mikroaneurisma. ELKOMIKA: Jurnal Teknik Energi Elektrik, Teknik Telekomunikasi, \& Teknik Elektronika, 3(1), 75. https://doi.org/10.26760/elkomika.v3i1.75

[3] Al Rivan, M. E., \& Juangkara, T. (2019). Identifikasi potensi glaukoma dan diabetes retinopati melalui citra fundus menggunakan jaringan syaraf tiruan. JATISI (Jurnal Teknik Informatika dan Sistem Informasi), 6(1), 43-48. https://doi.org/10.35957/jatisi.v6i1.158

[4] Satyarthi, D., Raju, B. A. N., \& Dandapat, S. (2016). Detection of diabetic retinopathy in fundus images using Vector Quantization Technique. 2016 Annual India Conference, INDICON, 7-10. https://doi.org/10.1109/INDCON.2006.302806

[5] Aji Seto Arifianto, Moechammad Sarosa, O. S. (2014). Klasifikasi stroke berdasarkan kelainan patologis dengan Learning Vector Quantiation. Eeccis, 8(2), 117-122.

[6] Santosa, S., Widjanarko, A., \& Supriyanto, C. S. (2017). Model prediksi penyakit ginjal kronik menggunakan Radial Basis Function. Pseudocode, 3(2), 163-170. https://doi.org/10.33369/pseudocode.3.2.163-170

[7] Hariyanto, R., Basuki, A., \& Hasanah, R. N. (2016). Klasifikasi penyakit mata katarak berdasarkan kelainan patologis dengan menggunakan algoritma Learning Vector Quantization. Jurnal Ilmiah NERO, 2(3), 177-182. 